\title{
Intestinal morphology, digestive organ size and digesta pH of broiler chickens fed diets supplemented with or without Moringa oleifera leaf meal
}

\author{
T.T. Nkukwana ${ }^{1}$, V. Muchenje ${ }^{1 \#}$, P.J. Masika ${ }^{2} \&$ B. Mushonga ${ }^{1}$ \\ ${ }^{1}$ Department of Livestock and Pasture Science, ${ }^{2}$ Agricultural Development and Research Institute, \\ University of Fort Hare, Private Bag X1314, Alice, Eastern Cape, South Africa
}

(Received 5 March 2014; Accepted 27 July 2015; First published online 30 August 2015)

\begin{abstract}
Copyright resides with the authors in terms of the Creative Commons Attribution 2.5 South African Licence.
See: http://creativecommons.org/licenses/by/2.5/za

Condition of use: The user may copy, distribute, transmit and adapt the work, but must recognise the authors and the South African Journal of Animal Science.
\end{abstract}

\begin{abstract}
The intestinal morphology and $\mathrm{pH}$ of digesta of broiler chickens at 35 days old were studied. Birds were reared on these dietary treatments $(\mathrm{T})$. T1, positive control, contained $668 \mathrm{~g}$ salinomycin and $500 \mathrm{~g}$ zinc bacitracin per $\mathrm{kg}$ of feed. Treatments, T2, T3 and T4, contained graded levels of Moringa oleifera leaf meal (MOLM) per $\mathrm{kg}$ of feed, namely starter (1, 3, $5 \mathrm{~g})$, grower $(3,9,15 \mathrm{~g})$ and finisher $(5,15,25 \mathrm{~g})$. T5 was a negative control (without supplementation). Birds were provided feed and water ad libitum. Birds in T3 had the highest proventriculus digesta $\mathrm{pH}$, and $\mathrm{T5}$ birds the lowest. Birds that were supplemented with MOLM and surprisingly those from the negative control - had significantly higher caecal digesta $\mathrm{pH}$, while $\mathrm{T} 1 \mathrm{had}$ the highest ileal digesta $\mathrm{pH}$. Duodenal villous length was longest in T2, and shortest in T4. Jejunal villous length was longest in T3 and shortest in T2 birds. T3 and T4 jejunal villi were widest, with T1 birds having the shortest. Ileal villous was longest in T2 and T5 birds, while T3 birds had the shortest. Duodenal surface area for absorption was larger in T2 and T5, and smaller in T4, while T3 had the largest ileal surface area, and T1 the smallest. The jejunal surface area was largest in T3 (53.2) and T4 (50.7), and smallest in T1 (25.0). The current results reveal a regulatory effect of MOLM on the gastrointestinal tract, which could be attributed to the coarseness of the diets, thus raising the $\mathrm{pH}$ and resulting in thicker digesta viscosity, which is a clear sign of a healthy gut.
\end{abstract}

Keywords: Digestive physiology, intestinal morphology, plant additives, poultry

\# Corresponding author: vmuchenje@ufh.ac.za

\section{Introduction}

Perceptions of consumers on raw and cooked meat quality have created significant interest in increasing the understanding of digestive physiology and the dynamics of the gut microflora (Dibner \& Richards, 2005). Physiological studies reveal that a functional gastrointestinal tract (GIT) is vital for the digestion and absorption of nutrients required for the bird's maintenance and growth (Mateos et al., 2002; Baurhoo et al., 2009). Gut integrity, its absorptive capacity and subsequent bird performance are improved by access to feed and water immediately post hatch, accompanied by intake of exogenous feed (Uni et al., 1998). Without a healthy gut, the best feed can be formulated, but does not ascertain optimal broiler performance (Yegani \& Korver, 2008). The surface area of the intestinal lining (mucosa) is greatly expanded owing to finger-like projections called villi, which in the avian gut exist throughout the length of the small and large intestines, steadily decreasing in height along the way (Hoerr, 2001).

At hatch, the anatomy and functional capacity of the digestive system of chicks are immature, with morphological and physiological changes of the GIT occurring only during the post-hatch period, including increases in the surface area for digestion and absorption (Panda et al., 2006). The early development of the GIT, together with supply organs such as the liver and heart, is of high priority in supplying nutrients to the rest of the body and the frame on which muscles accumulate (Zuidhof et al., 2006). The action of supply organs in the upper digestive tract of poultry is crucial to degrading feed to a form that is accessible to intestinal digestion since birds do not have teeth to facilitate mechanical breakdown of feed at ingestion (Rodgers et al., 2012).

In monogastric animals, dietary fibre content is the main substrate for bacterial fermentation because it cannot be hydrolysed by endogenous enzymes (Montagne et al., 2003). Qualitative and quantitative microbial colonization begin soon after birth, and develop gradually with age, rendering the maternal 
intestinal flora and surroundings as the main bacterial proliferation sources to the new-born digestive system (Fortun-Lamothe \& Boullier, 2007; Steiner \& Wegleitner, 2007). At this stage, this is a crucial process for all growing animals. However, in commercially bred poultry the process of intestinal microflora development is delayed because of the lack of natural contact between chicks and mother hens (Applegate et al., 2010). Consequently, the digestive tract becomes burdened with distinguishing between nutrients and nonpathogenic microorganisms from harmful microorganisms while ensuring good nutrient absorption, but excluding digestive microorganisms, harmful and non-harmful (Fortun-Lamothe \& Boullier, 2007; Leaphart \& Tepas III, 2007).

Recently, a number of additives derived from plants have been reported to contain aromatic properties that affect gut microflora, nutrient digestibility, intestinal morphology and meat quality of poultry, as with antibiotic growth promoters (Cross et al., 2007). Moringa oleifera Lam (Moringaceae) is documented to have an impressive range of medicinal uses, including growth promotion, and antimicrobial and antioxidant effects (Mbikay, 2012). For instance, cinnamic and caffeic acids, which are common representatives of a wide group of phenylpropane-derived compounds that have high oxidation properties (Cowan, 1999), are found in $M$. oleifera leaves. The nutritional profile of its fresh and dried leaves is reported to contain high levels of lipids and essential amino acids that are important in poultry productivity (Moyo et al., 2012) and selenium, a constituent of the cytosolic enzyme, glutathione peroxidase. Glutathione peroxidase is one of the most important antioxidants in the body and of significant importance for the digestive tract, gastrointestinal mucosa and the liver (Bengmark, 1998). Thus, further exploration of such morphological changes in gastrointestinal tissues, which are supposedly caused by plant feed additives, could provide further information on possible benefits to the digestive tract (Windisch et al., 2008; Issa et al, 2012). The objective of this experiment was to determine the effects of dietary additive supplementation of $M$. oleifera leaf meal (MOLM) on digestive organ size, intestinal morphology and digesta $\mathrm{pH}$ of broiler chickens.

\section{Materials \& Methods}

Fresh, green and undamaged $M$. oleifera leaves were air-dried during the day without exposure to direct sunlight, and being constantly turned over to avert fungal growth. After five days of drying, the leaves were ground to a fine powder to pass through a $0.15-\mathrm{mm}$ sieve. The leaf meal was tightly packaged in polythene plastic bags, sealed and kept at room temperature until required.

The feeding programme consisted of starter ( 0 to $21 \mathrm{~d}$ ), grower (22 to $28 \mathrm{~d}$ ) and finisher (29 to $35 \mathrm{~d}$ ) basal diets (Tables 1, 2 and 3), which were formulated to meet the birds' dietary nutrient requirements (NRC, 1994). Each basal feed was split into five treatment $(T)$ groups, which were prepared as follows. $T_{1}$ was the positive control with $668 \mathrm{~g}$ salinomycin/ton and $500 \mathrm{~g}$ zinc bacitracin/ton. Graded levels of MOLM were mixed with other ingredients in $T_{2}(1,3$ and $5 \mathrm{~g} / \mathrm{kg}), T_{3}(3,9$ and $15 \mathrm{~g} / \mathrm{kg})$ and $T_{4}(5,15$ and $25 \mathrm{~g} / \mathrm{kg})$ in the starter, grower and finisher diets, respectively. $T_{5}$ was a negative control with no supplementation. All diets from starter to finisher were pelleted. Proximate analysis was performed on all experimental diets and on MOLM samples according to the methods of the Association of Official Analytical Chemists (AOAC, 2000). The techniques described by Van Soest et al. (1991) were used to determine the concentrations of neutral detergent fibre (NDF) and acid detergent fibre (ADF).

A total of 2400 day-old unsexed Cobb 500 broiler chicks were purchased from a commercial hatchery, weighed and randomly allocated to 30 floor pens containing fresh wood shavings to the depth of $10 \mathrm{~cm}$ in an environmentally controlled house. The experiment was a completely randomized design divided into five dietary treatments with six replicate groups of 80 birds per pen ( 5 diets $\times 6$ replicates). House temperature was set and maintained at $34{ }^{\circ} \mathrm{C}$ during the first week, then reduced by $3{ }^{\circ} \mathrm{C}$ per week until $22{ }^{\circ} \mathrm{C}$ was reached. It was then maintained at this level until the end of the experiment. Birds were vaccinated for Marek's disease and Infectious bursal disease at the hatchery, but vaccines were not administered during rearing. Feed and fresh water were offered ad libitum throughout the 35-day rearing period. Bodyweights (BW) and feed intake (FI) per pen were recorded weekly, and feed per gain was calculated accordingly. Mortality was recorded daily (pen, date, BW and cause). Care and management of birds were in accordance with principles of animal care in experimentation (NRC, 1985). The experiment was also subjected to an assessment for its ethical acceptability and approved by the Ethics Committees of the University of Fort Hare (Animal Ethics No.: NKU01-1SWAP01).

At 35 days old, 12 birds were randomly selected per treatment, two per replicate, and fasted for six hours, with water offered ad libitum. Bodyweight was recorded per bird before they were electrically stunned at 70 volts and slaughtered by cervical dislocation. Birds were exsanguinated by a unilateral neck cut that severed the right carotid artery and jugular vein. After bleeding, scalding, plucking and washing, the feet, head and neck were removed. Carcasses were then eviscerated manually, and the GIT was excised. The small intestine was separated into duodenum (from gizzard outlet to the end of the pancreatic loop), jejunum 
(from the pancreatic loop to Meckel's diverticulum) and ileum (from Meckel's diverticulum to the caecal junction).

Table 1 Analysed Moringa oleifera leaf meal composition on as fed basis

$\begin{array}{lr}\text { Analysed nutrient composition } & \\ \text { Metabolizable energy }(\mathrm{MJ} / \mathrm{kg}) & 11.4 \\ \text { Crude protein }(\mathrm{g} / \mathrm{kg}) & 267.6 \\ \text { Crude fibre }(\mathrm{g} / \mathrm{kg}) & 157.2 \\ \text { Ether extract }(\mathrm{g} / \mathrm{kg}) & 56.3 \\ \text { Moisture }(\mathrm{g} / \mathrm{kg}) & 78.3 \\ \text { Ash }(\mathrm{g} / \mathrm{kg}) & 108.1 \\ \text { Acid detergent fibre }(\mathrm{g} / \mathrm{kg}) & 137.9 \\ \text { Neutral detergent fibre }(\mathrm{g} / \mathrm{kg}) & 200.8 \\ & \\ & \\ \text { Analysed mineral composition } & 3.2 \\ \text { Phosphorus }(\mathrm{g} / \mathrm{kg}) & 24.3 \\ \text { Potassium }(\mathrm{g} / \mathrm{kg}) & 28.1 \\ \text { Calcium }(\mathrm{g} / \mathrm{kg}) & 10.1 \\ \text { Magnesium }(\mathrm{g} / \mathrm{kg}) & 8.0 \\ \text { Sodium }(\mathrm{g} / \mathrm{kg}) & 192.0 \\ \text { Iron }(\mathrm{mg} / \mathrm{kg}) & 5.7 \\ \text { Copper }(\mathrm{mg} / \mathrm{kg}) & 23.8 \\ \text { Zinc }(\mathrm{mg} / \mathrm{kg}) & 86.8 \\ \text { Manganese }(\mathrm{mg} / \mathrm{kg}) & 33.1 \\ \text { Boron }(\mathrm{mg} / \mathrm{kg}) & 160.0 \\ \text { Aluminium }(\mathrm{mg} / \mathrm{kg}) & \end{array}$

Table 2 Dietary inclusion levels of Moringa oleifera leaf meal in $\mathrm{g} / \mathrm{kg}$

\begin{tabular}{lccc}
\hline \multirow{2}{*}{ Phase feeding regime } & \multicolumn{3}{c}{ Dietary treatments } \\
\cline { 2 - 4 } & T2 & T3 & T4 \\
\hline Starter $(0$ to 21 d) & 1 & 3 & 5 \\
Grower $(22$ to 27 d) & 3 & 9 & 15 \\
Finisher (28 to 35 d) & 5 & 15 & 25 \\
\hline
\end{tabular}

The $\mathrm{pH}$ measurements were performed by inserting the $\mathrm{pH}$ meter probe into the distal sections of the proventriculus, duodenum, jejunum, ileum and caecum. The contents of the duodenum, jejunum, ileum and caeca were collected, then the intestinal segments were flushed with distilled water and stored in airtight containers with formalin until required for histology measurements. The liver, gizzard, heart, spleen and bursa were weighed individually, and expressed as percentages of live bodyweight.

For intestinal morphological examinations, three cross-sections measuring $1 \mathrm{~mm}$ to $2 \mathrm{~mm}$ thick for each segment were prepared and enclosed in tissue cassettes. The tissues were fixed in $10 \%$ neutral buffered formalin over $24 \mathrm{~h}$. For each intestinal segment, a 2- $\mu \mathrm{m}$ section was placed onto a glass slide and stained with alcian blue and hematoxylin-eosin. Slides were viewed on the Motic stereo microscope (SMZ168 series), and visual measurements were taken of the villous height or length ( $\mu \mathrm{m}$ : distance from apex of 
villus to the junction of the villus and crypt) and villous width ( $\mu \mathrm{m}$ : distance from the junction to the basement membrane of the epithelial cell at the bottom of the crypt). For each parameter, six replicate measurements were taken per treatment, and the average of these values was used in statistical analysis. The surface area for absorption was calculated as: (intestinal portion width $\div 2 \times$ intestinal portion height).

The data on final performance, digestive organ size, intestinal morphology (villous height, width and surface area) and pH were analysed with the analysis of variance (ANOVA) of SPSS 20 (2011). Differences between treatment means were tested according to Duncan's multiple range test of SPSS. Data were presented as the least square means with standard errors. The model used was $Y_{i j}=\mu+\alpha_{i}+e_{i j}$, where $Y_{i j}=$ response variable, $\mu=$ the common mean, $\alpha_{i}=$ the effect of dietary treatment (T1, T2, T3, T4 and T5) and $e_{i j}$ $=$ the random error. Significant means value differences were evaluated by Duncan's multiple range test. Differences were considered significant at $P<0.05$.

Table 3 Composition of basal starter, grower and finisher diets on as-fed basis

\begin{tabular}{lccc}
\hline & \multicolumn{3}{c}{ Phase feeding regime } \\
\cline { 2 - 4 } Item & Starter & Grower & Finisher \\
& $(0$ to $21 \mathrm{~d})$ & $(22$ to $27 \mathrm{~d})$ & $(28$ to $35 \mathrm{~d})$ \\
\hline
\end{tabular}

Feed ingredients $(\mathrm{g} / \mathrm{kg})$

\begin{tabular}{|c|c|c|c|}
\hline Maize & 610.3 & 664.4 & 660.4 \\
\hline Soya oilcake & 311.5 & 249.1 & 253.5 \\
\hline Fishmeal & 25.4 & 33.3 & 40.0 \\
\hline Sunflower oil & 20.0 & 25.0 & 16.9 \\
\hline Limestone & 14.8 & 14.0 & 13.6 \\
\hline Monocalcium phosphate & 8.6 & 7.1 & 7.6 \\
\hline Methionine & 3.1 & 1.7 & 2.4 \\
\hline Salt & 3.3 & 2.9 & 3.1 \\
\hline${ }^{\star}$ Vitamin + mineral premix & 1.2 & 1.2 & 1.2 \\
\hline Sodium bicarbonate & 0.9 & & \\
\hline Choline chloride & 0.8 & 0.5 & 0.2 \\
\hline Lysine & 0.2 & 0.6 & 0.8 \\
\hline Threonine & 0.1 & 0.2 & 0.3 \\
\hline
\end{tabular}

Analysed composition ( $\mathrm{g} / \mathrm{kg})$

Crude protein $\quad 246.2$

$206.6 \quad 200.6$

Crude fibre

30.9

14.1

32.8

Ether extract

50.0

54.7

45.2

Calcium

11.2

10.1

9.8

Available phosphorus

Calculated composition

Metabolizable energy ( $\mathrm{MJ} / \mathrm{kg})$

`Supplied per kg of feed: 60 mg iron; 40 mg manganese; 4 mg copper; 70 mg zinc; 0.8 mg iodine; 0.3 mg selenium; 9000 IU vitamin A; 2000 IU vitamin D; 15 IU of vitamin E; 2 mg vitamin K; $1 \mathrm{mg}$ of vitamin $\mathrm{B}_{12} ; 0.30 \mathrm{mg}$ biotin; $250 \mathrm{mg}$ choline chloride; $0.75 \mathrm{mg}$ folic acid; $20 \mathrm{mg}$ niacin; $5.3 \mathrm{mg}$ pantothenic acid; $7.5 \mathrm{mg}$ pyridoxine; $7.5 \mathrm{mg}$ riboflavin and $2.1 \mathrm{mg}$ thiamine.

\section{Results and Discussion}

The effects of dietary treatments $(T)$ on final BW, FI, average daily gain (ADG) and feed conversion ratio or feed : gain (FCR) at $35 \mathrm{~d}$ old are shown in Table 4. There were no differences in BW, FI, ADG and FCR from $29 \mathrm{~d}$ to $35 \mathrm{~d}$ old, although in earlier results by Nkukwana et al. (2014) on the production 
performance of birds in this study BW, FI, ADG and FCR were highest $(P<0.05)$ in birds fed T3 and T4, respectively. Although not significant, there seemed to be a trend towards increased BW and ADG in T3 birds.

According to Rodgers et al. (2012), birds given first access to fibre-rich diets take time to adapt to the feed. However, this changes once the gizzard has developed properly, allowing birds to take full advantage of coarse feeds, thereby increasing their energy utilization efficiency. Moreover, bioactive compounds in certain plant additives can increase the secretion of digestive fluids and improve the immune system of broilers (Steiner \& Wegleitner, 2007). It is estimated that for every gram of feed ingested, the chicken gut secretes about $2 \mathrm{~g}$ of water, which facilitates digestion and absorption (Hoerr, 2001). These findings may explain the situation with birds that were fed T3 and T4 diets, respectively.

Table 4 shows the effect of diets supplemented with or without MOLM on digestive organ size. Neither antibiotics nor MOLM had an effect on the size of digestive organs, except for the bursa of Fabricius, which was significantly larger in T4 birds $(P<0.05)$. Birds do not have teeth to facilitate the mechanical breakdown of feed at ingestion. Hence, the actions of supply organs in the upper digestive tract of poultry are crucial to degrading feed to a form that is accessible to intestinal digestion (Rodgers et al., 2012). The early development of the GIT, together with supply organs such as the liver and heart, is of high priority in supplying nutrients to the rest of the body and developing the frame on which muscles accumulate (Zuidhof et al., 2006).

Table 4 Effect of diets supplemented with or without Moringa oleifera leaf meal (MOLM) on final bodyweight, average daily gain, feed intake, feed conversion ratio (feed : gain) and digestive organ weight of broilers chickens at 35 days old

\begin{tabular}{|c|c|c|c|c|c|c|c|}
\hline \multirow{2}{*}{$\begin{array}{l}\text { Experimental } \\
\text { period (d) and } \\
\text { parameter }\end{array}$} & \multicolumn{5}{|c|}{ Dietary treatments } & \multirow{2}{*}{ SEM } & \multirow{2}{*}{$P$-value } \\
\hline & T1 & T2 & T3 & T4 & T5 & & \\
\hline \multicolumn{8}{|c|}{ Performance parameters } \\
\hline Bodyweight (g) & 2119 & 2147 & 2236 & 2174 & 2177 & 14.0 & 0.094 \\
\hline ADG (g) & 60.6 & 61.3 & 63.9 & 62.1 & 62.2 & 0.4 & 0.094 \\
\hline Feed intake (g) & 3230 & 3160 & 3219 & 3147 & 3109 & 18.9 & 0.218 \\
\hline Feed : gain $(g: g)$ & $1.53^{\mathrm{b}}$ & $1.47^{\mathrm{ab}}$ & $1.44^{\mathrm{a}}$ & $1.45^{\mathrm{a}}$ & $1.43^{\mathrm{a}}$ & 0.01 & 0.053 \\
\hline \multicolumn{8}{|c|}{ Organ size, $\%$ of bodyweight } \\
\hline Liver & 2.2 & 2.2 & 2.2 & 2.1 & 2.4 & & NS \\
\hline Gizzard & 1.4 & 1.2 & 1.3 & 1.3 & 1.3 & & NS \\
\hline Heart & 0.4 & 0.5 & 0.5 & 0.5 & 0.5 & & NS \\
\hline Spleen & 0.10 & 0.09 & 0.10 & 0.11 & 0.11 & & NS \\
\hline Bursa of Fabricius & $0.18^{\mathrm{ab}}$ & $0.14^{\mathrm{b}}$ & $0.19^{\mathrm{ab}}$ & $0.23^{\mathrm{a}}$ & $0.19^{\mathrm{ab}}$ & & 0.014 \\
\hline
\end{tabular}

${ }^{\mathrm{a}-\mathrm{c}}$ Means within the same row that do not share a common superscript are significantly different $(P<0.05) ; \mathrm{n}=6$.

$\mathrm{T}_{1}$, positive control, $668 \mathrm{mg}$ salinomycin, $500 \mathrm{mg}$ zinc bacitracin; $\mathrm{T}_{2}, \mathrm{~T}_{3}$ and $\mathrm{T}_{4}$ contained graded levels of MOLM at $1 \%$, $3 \%$ and $5 \%$ of DM intake, respectively, and $\mathrm{T}_{5}$ : a negative control diet with no supplementation.

ADG: average daily gain.

In poultry, the presence of dietary fibre increases the rate of digesta passage as well as the physical capacity of the GIT, but may impair gizzard function and reduce nutrient digestibility and broiler performance if finely ground (Jiménez-Moreno et al., 2010). The gizzard is responsible for regulating GIT motility, and its poor development is believed to impair nutrient digestibility and broiler growth (González-Alvarado et al., 2008). In the current study, however, there were no differences in gizzard size. These findings are in agreement with the suggestion that broilers that are in good health may not respond to performancepromoting additives when reared under optimal bio-security conditions (Bozkurt et al., 2012).

As shown in Table 5 , the various segments of the digestive system had significantly different digesta $\mathrm{pH}$ levels $(P<0.05)$. Dietary $\mathrm{pH}$ for monogastric animals is usually reported to vary between 5.5 and 6.5 (Ao et al., 2008), and changes as digesta transit different segments of the GIT. As expected, digesta in the 
proventriculus were acidic, pH being lowest $(P<0.05)$ in birds that were fed low MOLM or negative control diets, while birds fed diets with antibiotics and high MOLM levels, respectively, had slightly less acidic digesta. Digesta $\mathrm{pH}$ drops gradually as digesta reach the proventriculus or glandular stomach, where hydrochloric acid and pepsinogen are secreted and mixed with digesta through muscular movements in the gizzard (Svihus, 2014). Feed form may also play a role in the digesta pH in the stomach. Svihus (2011) reported that average values in stomach $\mathrm{pH}$ for broiler chickens ranged between 3 and 4 for normal pelleted diets.

Table 5 Least square means ( \pm SE) on the effects of diets supplemented with or without Moringa oleifera leaf meal on intestinal digesta $\mathrm{pH}$ of broiler chicken at $35 \mathrm{~d}$ old

\begin{tabular}{lcrcrcr}
\hline \multirow{2}{*}{$\begin{array}{l}\text { Intestinal } \\
\text { portion }\end{array}$} & \multicolumn{7}{c}{ Dietary treatments } & $\begin{array}{c}\boldsymbol{P} \text { - } \\
\text { value }\end{array}$ \\
\cline { 2 - 6 } & \multicolumn{1}{c}{ T1 } & \multicolumn{1}{c}{ T2 } & \multicolumn{1}{c}{ T3 } & T4 & T5 & \\
Proventriculus & $3.7^{\mathrm{ab}} \pm 0.34$ & $3.3^{\mathrm{ab}} \pm 0.24$ & $3.9^{\mathrm{a}} \pm 0.26$ & $3.7^{\mathrm{ab}} \pm 0.23$ & $3.1^{\mathrm{b}} \pm 0.24$ & 0.048 \\
Duodenum & $5.3^{\mathrm{ab}} \pm 0.14$ & $5.6^{\mathrm{ab}} \pm 0.07$ & $5.2^{\mathrm{b}} \pm 0.14$ & $5.6^{\mathrm{ab}} \pm 0.11$ & $5.7^{\mathrm{a}} \pm 0.24$ & 0.047 \\
Jejunum & $5.7^{\mathrm{ab}} \pm 0.09$ & $6.0^{\mathrm{a}} \pm 0.13$ & $5.7^{\mathrm{ab}} \pm 0.07$ & $5.9^{\mathrm{ab}} \pm 0.13$ & $5.5^{\mathrm{b}} \pm 0.24$ & 0.044 \\
Ileum & $6.6^{\mathrm{a}} \pm 0.12$ & $6.1^{\mathrm{ab}} \pm 0.21$ & $5.7^{\mathrm{b}} \pm 0.35$ & $5.9^{\mathrm{ab}} \pm 0.31$ & $6.3^{\mathrm{ab}} \pm 0.23$ & 0.021 \\
Caecum & $6.1^{\mathrm{b}} \pm 0.09$ & $6.4^{\mathrm{a}} \pm 0.10$ & $6.5^{\mathrm{a}} \pm 0.14$ & $6.6^{\mathrm{a}} \pm 0.03$ & $6.6^{\mathrm{a}} \pm 0.06$ & 0.003
\end{tabular}

${ }^{\mathrm{a}-\mathrm{b}}$ Means within the same row that do not share a common superscript are significantly different $(P<0.05)$.

$\mathrm{T}_{1}$, positive control, $668 \mathrm{mg}$ salinomycin, $500 \mathrm{mg}$ zinc bacitracin; $\mathrm{T}_{2}, \mathrm{~T}_{3}$ and $\mathrm{T}_{4}$ contained graded levels of MOLM at $1 \%$, $3 \%$ and $5 \%$ of DM intake, respectively: $T_{5}$ : negative control diet with no supplement.

The gizzard, which is in close proximity to the stomach, had lower pH levels (Table 5). Besides, the pH of gizzard contents has been shown to decrease by a magnitude of 0.2 to 1.2 units when structural components or fibre materials are added to broiler diets (González-Alvarado et al., 2008; Sacranie et al., 2012). This may have been the case with birds that were supplemented with higher MOLM levels, as observed in the $\mathrm{pH}$ of their stomach digesta. The duodenal $\mathrm{pH}$ across treatments was lower than in the jejuna and ileal digesta, particularly in T1 $(P<0.05)$. Morphologically, this might have been expected. Khalaji et al. (2011) studied the effects of dried Artemisia sieberi leaves on digesta pH in broiler chickens, and reported a significant increase in $\mathrm{pH}$ of jejuna contents.

Nonetheless, the ileum, the last segment of the small intestine, which ends at the ileo-ceco-colic junction, had slightly higher $\mathrm{pH}$ levels than the jejunum (Table 5). Ileal $\mathrm{pH}$ was highest $(P<0.05)$, which may be due to the regulatory effect of antibiotic growth promoters. The ileum is thought to play a role as a site for water and mineral absorption, although some digestion and absorption of fat, protein and starch may occur. The functionality of the caeca is affected largely by diet, and the caeca enlarge because of an increased amount of fermentable material in the diet (Svihus, 2014), which may explain the rise in $\mathrm{pH}$ towards alkalinity. Gastric acidity can be detrimental to some of the microflora that inhabit the hindgut. Thus, maintaining caeca $\mathrm{pH}$ is important in promoting gut health (Ricke, 2003).

The effects of dietary supplementation with or without MOLM on the villi height, width and surface area in the duodenum, jejunum and ileum of broiler chickens are shown in Table 6. Birds fed T2 diets had the longest duodenal villous $(P=0.002)$, while T4 birds had the shortest. The jejunum villous was longest in T3 birds $(P<0.001)$, and shortest in T2. Post hatch, the GIT undergoes morphological changes, resulting in increases in intestinal length, villous height and density, which are accompanied by rises in pancreatic and digestive enzymes activity (Panda et al., 2006).

Jamroz et al. (2006) studied the effects of maize diets supplemented with plant extracts on broiler chickens. They reported a significant increase in jejuna wall villi. Apparently, rapid increases in villous height and surface area occur at different rates in chick intestinal segments, reaching a plateau at 6 to 8 days in the duodenum and after 10 days in the jejunum and ileum (Uni et al., 1996). Long villi are correlated with improved gut health, and an increase in duodenal and jejuna height or length (Baurhoo et al., 2009). Thus, birds whose GIT were stimulated earlier in life show better response to growth performance and nutrient utilisation efficiency.

As shown in Table 6, birds that were fed T3 and T4 had the widest jejuna villous $(P<0.001)$. But, as reported previously, narrow or thinner villous width, as observed in T1, does not necessarily mean that they are susceptible to breakage, resulting in contamination of carcasses during processing (Miles et al., 2006). In T1 birds, however, the antibiotic effect may not be ruled out in reducing villi properties. Miles et al. (2006) 
reported the smallest total villous area and shortest villous height and crypt depth in the ileum of chicks that were supplemented with the antibiotic virginiamycin. On the other hand, $M$. oleifera leaves contain glutathione, a conjugate element of glutamate, the most abundant amino acid in blood, which plays a vital role in maintaining mucosal integrity (Rao \& Samak, 2012). However, other than their health status, it is difficult to explain why birds on T5 diets had longer and wider intestinal segments than those on T1 diets. Although not significant, T5 birds exhibited a wider ileum even than the T4 birds.

Table 6 Least square means ( \pm SE) on the effects of diets supplemented with or without Moringa oleifera leaf meal on small intestine morphology of broiler chicken at $35 \mathrm{~d}$ old

\begin{tabular}{|c|c|c|c|c|c|c|}
\hline \multirow{2}{*}{$\begin{array}{l}\text { Intestinal } \\
\text { portion }\end{array}$} & \multicolumn{5}{|c|}{ Dietary treatments } & \multirow{2}{*}{$P$-value } \\
\hline & T1 & T2 & T3 & T4 & T5 & \\
\hline \multicolumn{7}{|c|}{ Villous height $(\mu \mathrm{m})$} \\
\hline Duodenum & $26.4^{\mathrm{a}} \pm 1.52$ & $28.4^{\mathrm{a}} \pm 1.54$ & $21.2^{\mathrm{b}} \pm 1.89$ & $19.9^{b} \pm 0.84$ & $26.3^{a} \pm 0.46$ & 0.002 \\
\hline Jejunum & $18.7^{\mathrm{bc}} \pm 0.90$ & $16.6^{c} \pm 0.72$ & $22.3^{\mathrm{a}} \pm 0.67$ & $20.7^{\mathrm{ab}} \pm 1.12$ & $20.4^{\mathrm{ab}} \pm 0.35$ & $<0.001$ \\
\hline Ileum & $6.4^{c} \pm 0.54$ & $12.1^{a} \pm 0.93$ & $7.5^{c} \pm 0.42$ & $12.0^{\mathrm{a}} \pm 0.23$ & $9.9^{b} \pm 0.32$ & $<0.0001$ \\
\hline \multicolumn{7}{|c|}{ Villous width $(\mu \mathrm{m})$} \\
\hline Duodenum & $3.8 \pm 0.34$ & $4.2 \pm 0.12$ & $4.2 \pm 0.34$ & $4.2 \pm 0.19$ & $4.6 \pm 0.29$ & 0.481 \\
\hline Jejunum & $2.7^{c} \pm 0.25$ & $3.5^{b} \pm 0.18$ & $4.8^{a} \pm 0.26$ & $4.9^{\mathrm{a}} \pm 0.18$ & $4.3^{a} \pm 0.27$ & $<0.0001$ \\
\hline Ileum & $3.5^{b} \pm 0.39$ & $4.8^{a} \pm 0.51$ & $3.1^{b} \pm 0.37$ & $3.9^{\mathrm{ab}} \pm 0.23$ & $4.8^{\mathrm{a}} \pm 0.35$ & 0.019 \\
\hline \multicolumn{7}{|c|}{ Villous surface area $(\mu \mathrm{m})$} \\
\hline Duodenum & $51.1^{\mathrm{ab}} \pm 7.10$ & $59.6^{a} \pm 4.16$ & $43.9^{b} \pm 4.94$ & $41.8^{\mathrm{b}} \pm 3.53$ & $59.7^{a} \pm 3.64$ & 0.052 \\
\hline Jejunum & $25.0^{c} \pm 1.64$ & $28.9^{c} \pm 2.37$ & $53.2^{\mathrm{a}} \pm 2.65$ & $50.7^{\mathrm{ab}} \pm 4.25$ & $43.6^{b} \pm 2.54$ & $<0.0001$ \\
\hline Ileum & $11.0^{b} \pm 1.68$ & $29.6^{a} \pm 5.01$ & $11.5^{\mathrm{b}} \pm 1.10$ & $23.3^{a} \pm 1.14$ & $23.6^{\mathrm{a}} \pm 1.49$ & $<0.0001$ \\
\hline
\end{tabular}

\footnotetext{
${ }^{\mathrm{a}-\mathrm{c}}$ Means within the same row that do not share a common superscript are significantly different $(P<0.05)$.

$\mathrm{T}_{1}$ : positive control, $668 \mathrm{mg}$ salinomycin, $500 \mathrm{mg}$ zinc bacitracin; $\mathrm{T}_{2}, \mathrm{~T}_{3}$ and $\mathrm{T}_{4}$ contained graded levels of MOLM at $1 \%$, $3 \%$ and $5 \%$ of DM intake, respectively, and $\mathrm{T}_{5}$ : a negative control diet with no supplementation.
}

The jejunum is largely responsible for digestion and absorption of all the major nutrients. Thus, increased villi height may be a consequence of greater need for digestive capacity (Svihus, 2014). The epithelial cells lining the villi facilitate the absorption of fluids and nutrients, secrete electrolytes and fluids, and regenerate and replace damaged cells or those lost to normal attrition (Hoerr, 2001). This may be the reason for the largest jejuna villi surface area $(P<0.0001)$ that was observed in T3 and T4 birds. As reported by Paul et al. (2007), the increase of villous height of various small intestine segments may be attributed to the role of the intestinal epithelium as a natural barrier to pathogenic bacteria and toxic substances that are present in the intestinal lumen. Furthermore, M. oleifera leaves contain short-chain carbohydrates, glycosides, which are reported to cause major increases in the height of the jejuna villi compared with AGP and AGP-free diets (Baurhoo et al., 2009).

The villi greatly expand the surface area of the intestinal lining (mucosa), which in the avian gut exist throughout the length of the small and large intestines, steadily decreasing in height along the way (Hoerr, 2001). This was evident in the current study, as the duodenal surface area for absorption was largest in T2 and T5 birds, and smallest in T4 birds (Table 6). The ileal villous surface area was largest in T3 birds and smallest in T1. The enhanced growth performance reported in Nkukwana et al. (2014) in birds that were supplemented with MOLM is directly related to the improved intestinal morphology and villous surface area.

Albeit it is not clear why a similar effect was not obtained in birds that were fed diets containing antibiotics, Baurhoo et al. (2009) reported improved gut integrity, as measured by changes in villi height, goblet cell number, and populations of beneficial bacteria, lactobacilli and bifidobacteria in the ceca of chicks that were fed fibre-rich diets. Thus, it is possible that the presence of short-chain monosaccharides in $M$. oleifera leaves was the main component that functioned as a competitive attachment site for pathogenic 
bacteria, carrying them out of the gut, rather than binding to the intestine, thus enhancing the growth of beneficial gut microflora. Moreover, the fluid in the upper small intestine plays a protective role, keeping pathogenic bacteria in suspension and washing them downstream, while encouraging the proliferation of growth-enhancing bacteria (Hoerr, 2001).

\section{Conclusion}

Findings from this study showed that ground $M$. oleifera leaves can be incorporated in broiler diets as a phytogenic feed additive up to $25 \mathrm{~g} / \mathrm{kg}$ with significant positive effects on intestinal morphology, digestive organ size and digesta $\mathrm{pH}$. Although the differences in the intestinal morphology and digesta $\mathrm{pH}$ of antibiotic and MOLM supplemented birds are difficult to explain, this study supports the hypothesis that under good hygienic conditions, strict biosecurity measures, clean litter, good ventilation and low stocking densities, bird health and productivity may be maintained. As such, there may be no need for antibiotics in the feed, as there would be minimum bacterial proliferation in the chicken gut and the environment. Further studies are necessary to evaluate the effects of ground $M$. oleifera leaves on gut microbial development and profile, ileal nutrient digestibility from $7 \mathrm{~d}$ to $35 \mathrm{~d}$ old, caecal fermentation and the production of volatile fatty acids.

\section{Acknowledgements}

The authors are grateful to the National Research Fund (NRF) Thuthuka Project and Govan Mbeki Research and Development Centre of University of Fort Hare for funding this study.

\section{References}

Ao, T., Cantor, A.H., Pescatore, A.J. \& Pierce, J.L., 2008. In vitro evaluation of feed-grade enzyme activity at $\mathrm{pH}$ levels simulating various parts of the avian digestive tract. Anim. Feed Sci. Technol. 140, 462-468.

AOAC, 2000. Official Methods of Analysis, 17th ed. Association of Official Analytical Chemists, Arlington, VA, USA.

Baurhoo, B., Ferket, P.R. \& Zhao, X., 2009. Effects of diets containing different concentrations of mannanoligosaccharide or antibiotics on growth performance, intestinal development, cecal and litter microbial populations, and carcass parameters of broilers. Poult. Sci. 88, 2262-2272.

Bengmark, S., 1998. Ecological control of the gastrointestinal tract. The role of probiotic flora. Gut 42, 2-7.

Bozkurt, M., Selek, N., Küçükyilmaz, K., Eren, H., Güven, E., Çatli, A.U. \& Çinar, M., 2012. Effects of dietary supplementation with a herbal extract on the performance of broilers infected with a mixture of Eimeria species. Br. Poult. Sci. 53, 325-332.

Cowan, M.M., 1999. Plant products as antimicrobial agents. Clinical Microbiology Reviews 12 (4), 564-582.

Cross, D.E., Mcdevitt, R.M. \& Acamovic, T., 2011. Herbs, thyme essential oil and condensed tannin extracts as dietary supplements for broilers, and their effects on performance, digestibility, volatile fatty acids and organoleptic properties. Br. Poult. Sci. 52, 227-237.

Dibner, J.J. \& Richards, J.D., 2005. Antibiotic growth promoters in agriculture: history and mode of action. Poult. Sci. 84, 634-643.

Fortun-Lamothe, L. \& Boullier, S., 2007. A review on the interactions between gut microflora and digestive mucosal immunity. Possible ways to improve the health of rabbits. Livest. Sci. 107, 1-18.

González-Alvarado, J.M., Jiménez-Moreno, E., Valencia, D.G., Lázaro, R. \& Mateos, G.G., 2008. Effects of fibre source and heat processing of the cereal on the development and $\mathrm{pH}$ of the gastrointestinal tract of broilers fed diets based on corn or rice. Poult. Sci. 87, 1779-1795.

Hoerr, F.J., 2001. Intestinal integrity and the impact of losing it. Elanco Poultry Health Conference, Atlanta, January 21st.

Issa, K.J. \& Omar, J.M.A., 2012. Effect of garlic powder on performance and lipid profile of broilers. Open J. Anim. Sci. 2 (2), 62-68.

Jamroz, D., Wertelecki, T., Houszka, M. \& Kamel, C., 2006. Influence of diet type on the inclusion of plant origin active substances on morphological and histochemical characteristics of the stomach and jejunum walls in chicken. J. Anim. Physiol. Anim. Nutr. 90, 255-268.

Jiménez-Moreno, E., González-Alvarado, J.M., González-Sánchez, D., Lázaro, R. \& Mateos, G.G., 2010. Effects of type and particle size of dietary fibre on growth performance and digestive traits of broilers from 1 to 21 days of age. Poult. Sci. 89, 2197-2212.

Khalaji, S., Zaghari, M., Hatami, K., Hedari-Dastjerdi, S., Lotfi, L. \& Nazarian, H., 2011. Black cumin seeds, Artemisia leaves (Artemisia sieberi), and Camellia L. plant extract as phytogenic products in broiler diets and their effects on performance, blood constituents, immunity, and cecal microbial population. Poult. Sci. 90, 2500-2510. 
Leaphart, C.L. \& Tepas III, J.J., 2007. The gut is a motor of organ system dysfunction. Surgery 141 (5), 563569.

Lou, Y.J., Liu, H.L., Wang, J. \& Sun, Z.J., 2010. Determination and comparison of digestion kinetics of two fibre sources in geese (Anseris). S. Afr. J. Anim. Sci. 40, 70-77.

Mateos, G.G., La'zaro, R. \& Gracia, M.I., 2002. The feasibility of using nutritional modifications to replace drugs in poultry feeds. J. Appl. Poult. Res. 11, 437-452.

Mbikay, M., 2012. Therapeutic potential of Moringa oleifera leaves in chronic hyperglycemia and dyslipidemia: A Review. Frontiers in Pharmacology 3 (24), 1-12.

Miles, R.D., Butcher, G.D., Henry, P.R. \& Littell, R.C., 2006. Effect of antibiotic growth promoters on broiler performance, intestinal growth parameters, and quantitative morphology. Poult. Sci. 85, 476-485.

Montagne, L., Pluske, J.R. \& Hampson, D.J., 2003. A review of interactions between dietary fibre and the intestinal mucosa, and their consequences on digestive health in young non-ruminant animals. Anim. Feed Sci. Technol. 108, 95-117.

Moyo, B., Oyedemi, S., Masika, P.J, \& Muchenje, V., 2012. Polyphenolic content and antioxidant properties of Moringa oleifera leaf extracts and enzymatic activity of liver from goats supplemented with Moringa oleifera leaves/ sunflower seed cake. Meat Sci. 91, 441-447.

Namkung, H., Li, M.L., Gong, J., Yu, H., Cottrill, M. \& de Lange, C.F.M., 2004. Impact of feeding blends of organic acids and herbal extracts on growth performance, gut microbiota and digestive function in newly weaned pigs. Canadian J. Anim. Sci. 84, 697-704.

NRC, 1985. National Research Council (Guide for the Care and Use of Laboratory Animals). National Academy Press, Washington DC, USA (Publication no. 85: 123).

NRC, 1994. Nutrient Requirements of Poultry, 9th ed. National Academy Press, Washington DC, USA.

Panda, A.K., Sunder, G.S., Rao, S.V.R. \& Raju, M.V.L.N., 2006. Early nutrition enhances growth and speeds up early development. World Poult. Mag. 22 (4), 15-16.

Paul, S.K., Halder, G., Mondal, M.K. \& Samanta, G., 2007. Effect of organic acid salt on the performance and gut health of broiler chicken. J. Poult. Sci. 44, 389-395.

Rao, R.K. \& Geetha, S., 2012. Role of glutamine in protection of intestinal epithelial tight junctions. J. Epithel. Biol. Pharmacol. 5 (Suppl. 1-M7), 47-54.

Ricke, S.C., 2003. Perspectives on the use of organic acids and short chain fatty acids as antimicrobials. Poult. Sci. 82, 632-639.

Rodgers, N.J., Choct, M., Hetland, H., Sundby, F. \& Svihus, B., 2012. Extent and method of grinding of sorghum prior to inclusion in complete pelleted broiler chicken diets affects broiler gut development and performance. Anim. Feed Sci. Technol. 171, 60-67.

Sacranie, A., Svihus, B., Denstadli, V., Moen, B., Iji, P.A. \& Choct, M., 2012. The effect of insoluble fibre and intermittent feeding on gizzard development, gut motility, and performance of broiler chickens. Poult. Sci. 91, 693-700.

Spring, P., 2012. Shining a light on gut health. World Poult. Mag. 28 (6), 18-19.

SPSS, 2011. Statistical Package for the Social Sciences, 2011. 'SPSS 7.5 for Windows.' (SPSS: Chicago, IL).

Steiner, T. \& Wegleitner, K., 2007. Natural growth promoters for gut health management. World Poult. Mag. 23 (7), 22-24.

Svihus, B., 2011. The gizzard: Function, influence of diet structure and effects on nutrient availability. World's Poult. Sci. J. 67, 207-223.

Svihus, B., 2014. Function of the digestive system. J. Appl. Poult. Res. 23, 306-314.

Uni, Z., Ganot, S. \& Sklan, D., 1998. Post-hatch development of mucosal function in the broiler small intestine. Poult. Sci. 77, 75-82.

Van Soest, P.J., Robertson, J.B. \& Lewis, B.A., 1991. Methods for dietary fibre, neutral detergent fibre and non-starch polysaccharides in relation to animal nutrition. J. Dairy Sci. 74, 3583-3597.

Windisch, W., Schedle, K., Plitzner, C. \& Kroismayr, A., 2008. Use of phytogenic products as feed additives for swine and poultry. J. Anim. Sci. 86, E140-E148.

Yegani, M. \& Korver, D.R., 2008. Factors affecting intestinal health in poultry. Poult. Sci. 87, 2052-2063.

Zuidhof, M.J., Carney, V.L., Schneider, B.L., Renema, R.A., Robinson, F.E. \& Betti, M., 2006. Broiler meat quality and yield dynamics. Poultry Service Industry Workshop, October 3rd - 5th, pp. 79-88. 